\title{
KESETARAAN PRIA DAN WANITA (GENDER) MENURUT ALKITAB
}

\author{
Oleh : Pdt. Dr. Yehuda Mandacan, M.Th \\ Pembantu Ketua III Bidang Kemahasiswaan
}

\begin{abstract}
ABSTRAK
Masalah gender bukan masalah baru. Masalah perdebatan gender dari para ahli dari waktu ke waktu mewarnai kehidupan manusia menentukan mana yang manusia ciptaan Allah dan mana yang tidak, bukan hanya terdapat antara seluruh makhluk ciptaan Allah tetapi terbawa sampai kepada pribadi manusia baik laki-laki maupun perempuan. Namun Alkitablah yang akan menjadi kunci jawaban bagi setiap pendapat manusia. Sehingga tidak lagi seorang pun mencari jalan untuk menentukan kebenarannya sendiri-sendiri. Sebab Alkitab dalam Perjanjian Lama maupun Perjanjian Baru akan menyatakan kebenaran bahwa baik Laki-laki maupun perempuan adalah setara di hadapan Tuhan sebagai pencipta. Pada pembahasan ini penulis akan melakukan kajian mengenal kesetaraan Gender dalam perspektif Alkitab Pada bab terdahulu penulis telah memaparkan mengenai komunitas masyarakat Arfak secara global yang di dalamnya tercakup mengenai wanita. Adapun tujuan pembahasan dalam bab ini ialah untuk menemukan sebuah landasan biblikal yang merupakan kebenaran hakiki mengenai kesetaraan gender. Namun sebelum melakukan pembahasan secara alkitabiah, penulis akan melakukan kajian singkat berkenaan dengan isu gender yang terus berkembang dewasa ini. Di samping memberikan informasi, pemahaman ini juga guna membandingkan kebenaran yang ada dalam Alkitab. Tentu sebagai orang percaya haruslah mengakui legitimasi Alkitab sebagai otoritas kebenaran tertinggi. Apapun
\end{abstract}


kebenaran yang diajarkan oleh Alkitab haruslah dilakukan secara mutlak sekalipun tembok-tembok budaya sangat menghalangi. Namun perlu dilakukan langkah-langkah dan strategi yang bijak agar tidak melahirkan konfrontasi negatif yang berakhir pada penolakan.

\section{Kata Kunci : Kesetaraan, Pria, Wanita}

\section{A. KAJIAN UMUM MENGENAI PANDANGAN KESETARAAN PRIA-WANITA}

Isu-isu mengenai gender (jenis kelamin) merupakan masalah yang terus bergulir hingga dewasa ini. Secara praktis hal ini ditemukan dalam kehidupan sehari-hari berkenaan dengan status, hak, tugas dan tanggung jawab antara pria dan wanita. Benturan-benturan ini sering ditemukan baik dalam keluarga, dunia keaja, kehidupan masyarakat dan juga dalam keyakinan, seperti dalam kekristenan.

\section{Istilah Kesetaraan Gender Dan Maknanya}

Istilah gender berasal dan bahasa Latin (genus), artinya jenis atau tipe Kemudian istilah ini dipergunakan untuk jenis kelamin (laki-laki atau perempuan) Dalam Kamus Bahasa Inggris istilah ini juga diberi arti jenis kelamin. Istilah gender belum masuk dalam perbendaharaan kata Kamus Besar Bahasa Indonesia. Tetapi dalam pemakaian berikutnya istilah nu selalu dikaitkan dengan budaya Istilah gender lebih banyak menunjuk kepada perbedaan status dan peranan laki-laki dan perempuan yang terbentuk dalam proses sosial dan budaya yang panjang.

Orang yang pertama sekali memakai istilah gender dalam makna yang berbeda dengan jenis kelamin adalah Ann Oakley. Dikemukakannya bahwa gender adalah perbedaan sosial yang berpangkal pada perbedaan jenis kelamin, dalam hal mana perbedaan 
sosial itu dibakukan dalam tradisi dan sistem budaya masyarakat). ${ }^{1}$ Pembakuan perbedaan sosial itu amat ditekankan oleh Wilson dan Lindsey. $^{2}$ Wilson misalnya mengartikan gender sebagai suatu dasar untuk menentukan perbedaan sumbangan laki-laki dan perempuan pada kebudayaan dan kehidupan kolektif yang sebagai akibatnya mereka menjadi berbeda yaitu laki-laki dan perempuan. Sementara itu Lindsey mengatakan bahwa yang termasuk kajian gender adalah semua ketetapan masyarakat perihal penentuan seseorang sebagai laki-laki atau perempuan. Jadi gender itu merupakan harapan-harapan budaya terhadap laki-laki dan perempuan. Budaya yang biasanya dikaitkan dengan pembahasan gender dan yang mengakibatkan ketidak adilan gender adalah dominasi patriarkhat, yaitu suatu sistem dan praktikpraktik sosial dan politik di mana kaum laki-laki menguasai, menindas, dan mengeksploitasi perempuan. Perbedaan laki-laki dan perempuan yang dihasilkan dominasi patriarkhat tersebut, yang kemudian melahirkan keyakinan bahwa laki-laki berstatus dan mempunyai hak yang lebih dan perempuan, dan bahwa peran perempuan terbatas hanya pada area tertentu, dan ujung-ujungnya adalah diskriminasi terhadap perempuan dalam status dan peranan.

Jadi perbedaan antara laki-laki dan perempuan dapat ditinjau dari sudut gender dan dari segi seks (biologis) dan sudut gender peran dan tanggung jawab laki-laki dan perempuan (1). bukan dikodratkan oleh Tuhan tetapi ditentukan oleh masyarakat (konstruksi sosial), (2). dapat berubah bahkan dipertukarkan sesuai dengan budaya, tempat, dan keadaan yang tertentu dan (3). berbeda-beda antara kelompok yang satu dengan yang lainnya sesuai budaya, tempat, dan keadaan masingmasing kelompok.

Berbeda dengan sudut pandang seks (blologis), perbedaan laki-laki dan perempuan dikodratkan Tuhan tidak dapat berubah apalagi dipertukarkan, sehingga perbedaan itu berlaku sepanjang masa dan di mana pun serta bagi golongan mana saja. Misalnya peran dan tanggung jawab perempuan untuk mengandung dan melahirkan tidak dapat berubah atau dipertukarkan déngan laki-laki. Tetapi peran dan tanggung jawab dalam merawat dan mendidik yang selama ini

\footnotetext{
${ }^{1}$ F. Djannah, Teori dan Kosep Gender. Dialog Interaktif antar Tokoh Agama dan Masyarakat (Sosial-Budaya) Provinsi Sumatera Utara. Medan, 26 Juli 2006.

${ }^{2}$ L. L. Lindsey, Gender Roles: A Sociological Perspective (New Jersey: Prentice, 1990), hlm. 87.
} 
dianggap kewajiban perempuan dapat disamakan dipertukarkan dengan laki-laki. Peran dan tanggung jawab menurut gender merupakan warisan satu generasi atasan, ke generasi berikutnya. Memang peran dan tanggung jawab itu telah melewati proses negosiasi tetapi lama kelamaan dianggap alamiah, normal, bahkan identik dengan kodrat, sedangkan yang melanggarnya dianggap tidak normal tetapi melawan kodrat.

Kata gender sering dikaitkan dengan kesetaraan dan keadilan serta diskriminasi. Kesetaraan gender adalah adanya keseimbangan, kesepadanan, dan kesejajaran peran dan tanggung jawab laki-laki dan perempuan bagi hal-hal yang tidak dikodratkan. Jadi dalam kesetaraan dan keadilan gender (KKG) terdapat suatu kondisi yang setara (equality) dan adil (equity) dalam hak, kesempatan, dan hubungan kerja sama antara laki-laki dan perempuan. Sedangkan diskriminasi gender adalah setiap tingkah laku yang membedakan, menyingkirkan, membatasi, pilih kasih yang dilakukan karena alasan gender. Dan tingkah laku ini mengakibatkan penolakan pengakuan dan kebahagiaan serta penolakan keterlibatan dan pelanggaran atas pengakuan asasi dan persamaan antara laki-laki dan perempuan dalam bidang ekonomi, politik, dan sosial-budaya. ${ }^{3}$

\section{Permasalahan Umum Mengenai Kesetaraan Gender}

Kesetaraan gender tidak lepas dari isu pemberdayaan perempuan dan gerakan feminisme. Dan ini tidak bisa dilepaskan dari sejarah kelam masyarakat Barat pada abad-abad pertengahan. Menurut McKay dalam bukunya a History of Western Society, ${ }^{4}$ terdapat bukti-bukti kuat yang mengindikasikan bahwa perempuan telah dianggap sebagai makhluk inferior, bahkan pada tahun 1595, seorang profesor dari Wittenberg University melakukan perdebatan serius mengenai apakah perempuan itu manusia atau bukan. Kehidupan keras dialami oleh perempuan-perempuan di Eropa abad Pertengahan. Dalam esai Francis Bacon tahun 1612 yang berjudul Marriage and Single Life (Kehidupan

${ }^{3}$ R. Sinulingga, Perempuan Perlukah Kita Menggugat Kitab Suci? Kurban yang Berbau Harum, peny., Darius Duhut, Badan Penelitian dan Pengembangan PGI Jakarta (Jakarta: P01, 1998), hlm. 28.

${ }^{4}$ McKay, a History of Western Society, Journal Islamia Republika (9 April 2009). 
Perkawinan dan Kehidupan Sendiri), disebutkan banyak laki-laki memilih untuk hidup lajang, jauh dari pengaruh buruk perempuan dan beban anak-anak sehingga dapat berkonsentrasi pada kehidupan publiknya. ${ }^{5}$

Karena diperlakukan sebagai makhluk tertindas, maka muncullah kemudian berbagai gerakan pembebasan perempuan. Termasuk membebaskan diri dari kungkungan agama. Dalam bukunya, yang berjudul Membiarkan Berbeda?, pakar Ilmu Gizi IPB, Ratna Megawangi, menyebutkan, ide kesetaraan Gender bersumber pada paham Marxis, yang menempatkan perempuan sebagai kelas tertindas dan laki-laki sebagai kelas penindas. ${ }^{6}$ Institusi keluarga yang mendiskriminasi perempuan harus dihilangkan atau diperkecil perannya apabila masyarakat komunis ingin ditegakkan, yaitu masyarakat yang tidak ada kaya-miskin, dan tidak ada perbedaan peran antara laki-laki dan perempuan. Agenda feminis mainstream, semenjak awal abad ke-20, adalah bagaimana mewujudkan kesetaraan gender secara kuantitatif, yaitu laki-laki dan perempuan sama-sama berperan, baik di luar maupun di dalam rumah. Tidak ada bedanya laki-laki dan perempuan. Urusan rumah tangga dan anak adalah urusan sama-sama. Mereka percaya, bahwa perbedaan peran berdasarkan gender adalah karena produk budaya, bukan karena perbedaan biologis atau hal yang alamiah.

Tahun 1970an, para feminis mulai mengusung konsep kesetaraan gender sebagai aifran utama gerakan mereka. Para feminis berpendapat gender merupakan konstruksi sosial, dan berbeda dengan "sex" yang merujuk pada anatomi biologis. Gender dipengaruhi oleh kondisi sosial-budaya, agama, dan hukum yang berlaku di masyarakat serta faktor-faktor lainnya. Lips dalam a New Psychology of Women berpendapat, gender tidak hanya terdiri dari dua jenis, yaitu feminin dan maskulin. Tetapi, rnenurutnya, ada gender ketiga yang bersifat cair dan bisa berubah-ubah, dan telah dikenal pada berbagai macam budaya yang berbeda. Gender ketiga ini tidak bisa dikategorikan sebagai

\footnotetext{
2009).

${ }^{5}$ Francis Bacon, "Marriage and Single Life" Journal Islamia Republika , (9 April

${ }^{6}$ Ratna Megawangi, Membiarkan Berbeda. http://muxiim. comiblogs/ najmasyiralkesetaraan-gender/.
} 
feminin atau maskulin, tetapi mereka adalah kaum homoseksual dan transvestite. $^{7}$

Tidak heran timbul berbagai reaksi dan wanita mulai dan yang sekedar memendam rasa tidak puas lungga yang beram bersuara dan bah yang lebih ekstrim lagi ialah memberontak terhadap tatanan masyarakat yang telah mengakar.

\section{Dasar Alkitabiah Mengenai Kesetaraan Gender}

Bagi orang Kristen yang saleh dan mengamalkan imannya dengan benar, sesungguhnya tidak terlalu menemukan permasalahan yang berarti berkenaan dengan gender. Tetapi tidak dapat dipungkiri bahwa dalam dunia kekristenan juga mengalami pergolakan panjang mengenai konsep kesetaraan gender. Produk dan perdebatan ini ialah lahirnya teologi feminisme. Sebelum melangkah lebih jauh, memang harus diakui bahwa dalam dunia kekristenan yang diwakili oleh Bapa gereja seperti Tertulian yang mengatakan bahwa "perempuan adalah pintu gerbang setan, pembelot pertama hukum Allah. "Bapa-bapa gereja pada waktu itu banyak dipengaruhi oleh ajaran Yunani dan Talmud. Demikian juga, tokoh reformator Martin Luther, mengemukakan bahwa perempuan memang diciptakan lebih lemah intelektualitasnya ketimbang laki-laki, perempuan bertanggung jawab untuk kejatuhan manusia ke dalam dosa, dan pernikahan adalah satu-satunya panggilan kodrati baginya. Tokoh reformator lain yaitu Johanes Calvin, menegaskan bahwa menurut Kejadian 1:26-28, hanya laki-laki yang diciptakan segambar dengan Allah, sedangkan perempuan berstatus kelas dua (a secondary degree). ${ }^{8}$ Khususnya dalam Kejadian 2:18 dia disebut "penolong" Karena itu sepanjang zaman perempuan harus dikucilkan dari kepemimpinan publik. Selain itu, para penafsir tradisional sudah begitu terbiasa mengutip sebagian ayat-ayat Alkitab (yang "berbicara negatif" tentang status (perempuan) untuk membuktikan bahwa perempuan itu berasal dari laki-laki, untuk lakilak, sepanjang waktu bahkan kekal statusnya lebih rendah dari laki-laki.

Dalam Alkitab memang dapat ditemukan perbedaan status dan peran serta tanggung jawab laki-laki dan perempuan baik dari sudut (2003).

${ }^{7}$ Hilary M. Lips, A New Psychology of Women; Gender, Culture, and Ethnicity

${ }^{8}$ R. Sinulingga, Perempuan Perlukah, hlm. 28. 
pandang gender maupun seks ditemukan niat, peran, serta tanggung jawab laki-laki dan perempuan yang bukan kodrat tetapi merupakan konstruksi sosial. Karenanya status dan peran ini dapat dipertukarkan, berubah-ubah pada situasi, kondisi, dan kelompok yang berbeda satu dengan lainnya.

Menurut William Barclay, pandangan orang Yahudi yang merendahkan wanita nampak dalam doa pagi pria Yahudi yang terdapat dalam Talmud. Di dalam doanya setiap pagi orang Yahudi bersyukur karena Tuhan tidak menciptakannya sebagai seorang kafir, budak atau wanita. ${ }^{9}$ Itulah sebabnya pada zaman Bapak gereja kaum wanita hampir-hampir tidak memiliki bagian di dalam gereja. ${ }^{10}$ Wanita pada masa itu dianggap rendah dan berada di bawah dominasi pria. Keadaan ini terus berlanjut selama berabad-abad tanpa ada perubahan.

\section{Manusia Dalam Sejarah Penciptaan}

Seperti diungkapkan di atas bahwa sekalipun adat dan kebiasaan di suatu masyarakat sangat kuat mempengaruhi wacana pikiran setiap orang yang berasal dari dan atau memiliki ciri khas adat dan kebiasaan tersebut, namun ada sesuatu yang lebih tinggi yang harus dihargai dan dijunjung tinggi, yaitu apa yang dikatakan Alkitab. Dalam kehidupan sehari-hari pada sebuah suku atau bangsa perbedaan pria wanita itu memang harus ada, tetapi sejarah dalam penciptaan haruslah menjadi panutan yang memimpin setiap orang percaya untuk mengetahui identitas diri dan yang menyatakan kebenaran untuk dipercayai dan menjadi petunjuk untuk mengarahkan setiap orang kembali kepada kebenaran itu.

Alkitab Perjanjian Lama, di Kejadian 1:1-25 Allah menjadikan bumi dan langit serta segala isinya baik benda-benda mati maupun makhluk-makhluk hidup. Tuhan melihat semuanya baik tanpa kekurangan apapun pada ciptaan-Nya. Dalam pasal 1:26 dan 1:27 Alkitab berkata: Berfirmanlah Allah: "Baiklah Kita menjadikan manusia menurut gambar dan rupa Kita, supaya mereka berkuasa atas

\footnotetext{
${ }^{9}$ William Barclay, dalam Veritas, Jurnal Teologia dan Pelayanan , 4/2 (Oktober 2003), hlm. 266.

${ }^{10} \mathrm{Hal}$ ini tidak berarti bahwa pada masa itu sama sekali tidak ada tokoh wanita yang terkemuka dalam gereja, hanya saja bapak-bapak gereja tidak menyukai teolog wanita.
} 
ikan-ikan di laut dan burung-burung di udara dan atas ternak dan atas seluruh bumi dan atas segala binatang melata yang merayap di bumi.' Maka Allah menciptakan manusia itu menurut gambarNya, menurut gambar Allah diciptakanNya dia; laki-laki dan perempuan diciptakanNya mereka.

Jadi manusia pria dan wanita diciptakan dalam rupa dan gambar yang sama dengan Allah. Ayat firman Tuhan ini dapat memberikan tekanan kepada Allah sebagai pribadi yang dahsyat, di mana Ia memilih menjadikan manusia sebagai makhluk yang sangat sempurna daripada ciptaan-Nya yang lain yang menunjukkan bahwa perbedaan hanya ada pada perbandingan manusia dengan ciptaan lainnya. Sedangkan di antara manusia baik laki-laki maupun perempuan tidak ada sedikit pun perbedaan. Sebab diciptakan serupa dan segambar dengan pencipta.Di dalam buku Wycliffe dijelaskan:

Menurut gambar (Selem) dan rupa kita (demüt). Sekalipun dua istilah sinonim ini memiliki arti yang berbeda, tampaknya tidak dimaksudkan untuk menyampaikan aspek yang berbeda dari diri Allah. Jelas bahwa manusia memiliki kedudukan yang jauh lebih tinggi, sebab Allah menciptakan manusia untuk menjadi tidak fana, dan menjadikan manusia suatu gambar khusus dan keabadiannya sendini. Manusia adalah makhluk yang dapat dikunjungi serta berhubungan dan bersekutu dengan Khaliknya. Sebaliknya Tuhan dapat mengharapkan manusia untuk menanggapi-Nya dan bertanggung jawab kepada-Nya. Manusia diberi kuasa untuk memiliki hak memilih, bahkan hingga ke tingkat tidak menaati khaliknya manusia harus menjadi wakil dan penatalayanan Allah yang bertanggung jawab di bumi, melaksanakan kehendak Allah dan menggenapi maksud sang Khalik"11

Tafsiran tersebut di atas menjelaskan bahwa manusia diciptakan sebagai makhluk yang berkualitas tinggi dibandingkan dengan ciptaan lain. Lebih lagi dikatakan diciptakan untuk berhubungan dengan sang Pencipta, ini sangat berbeda dengan ciptaan yang lain. Allah bukan saja menjadikan manusia lebih berbeda tetapi seperti kata tafsiran tersebut

\footnotetext{
${ }^{11}$ Kyle M. Yates, "Penciptaan," dalam Tafsiran Alkitab WYCLIFFE, peny., Charles F. Pfejffer dan Everett F. Harrison (Malang: Gandum Mas, 2004); Perjanjian Lama: Kejadian - Ester, hlm. 1:29.
} 
bahwa manusia dapat bertanggung jawab kepada Penciptanya. Itu berarti bahwa manusia dipandang istimewa sehingga hak dan tanggung jawab istimewa pun diberikan, yaitu untuk menguasai bumi. Suatu otoritas diberikan penuh.

Dalam terjemahan Alkitab menurut versi King James, memang penulis sangat kurang dan atau terbatas sekali dalam menterjemahkan dari bahasa Inggris, namun sangat penting untuk menjadi suatu perbandingan dalam penulisan ini, Kejadian 1:26-28 kira-kira diterjemahkan ke dalam bahasa Indonesia seperti ini:

Dan Tuhan yang berkata, mari Kita membuat manusia di dalam gambaran Kita, menjadi persamaan Kita: dan biarkan mereka mempunyai kuasa di atas ikan dan laut, dan di atas unggas dan udara, dan di atas lembu, dan di atas semua bumi, dan di atas tiap-tiap hal yang merambat atas bumi. Maka Tuhan menciptakan manusia di dalam gambaran milik-Nya, di dalam gambaran Tuhan diciptakan dia; wanita dan pria diciptakan mereka. Dan Tuhan memberkati mereka, dan Tuhan berkata bagi mereka, jadilah penuh keberhasilan, dan mengalikan, dan mengisi bumi, dan menundukkan itu: dan mempunyai kuasa di atas ikan dan laut, dan di atas unggas dan udara, dan di atas semua yang hidup yang bergerak di atas bumi. ${ }^{12}$

Dalam Alkitab terjemahan baru bahasa Indonesia kalimat "Baiklah Kita menjadikan manusia menurut gambar dan rupa Kita." Menurut terjemahan King James, kalimat itu berbunyi: "Mari Kita membuat manusia di dalam gambaran Kita, menjadi persamaan Kita." Sedangkan dalam Alkitab Bahasa Indonesia sehari-hari diterjemahkan demikian: 1:26 Kemudian Allah berkata: Sekarang Kita akan membuat manusia yang akan menjadi seperti kita dan menyerupai Kita. Mereka akan berkuasa atas ikan-ikan, burung-burung, dan segala binatang lain, baik jinak maupun liar, (Sebuah terjemahan kuno: binatang lain, baik jinak maupun liar, Ibrani binatang jinak dan seluruh bumi). Baik besar maupun kecil 1:27, Demikianlah Allah menciptakan manusia, dan dijadikannya mereka seperti diri-Nya sendiri. Diciptakan-Nya mereka laki-laki dan perempuan. 1:28 Kemudian diberkati-Nya mereka dengan ucapan "Beranak cuculah, yang banyak, supaya keturunanmu mendiami seluruh muka bumi serta menguasainya, kamu Kutugaskan

\footnotetext{
${ }^{12}$ Kejadian 1:26-28.
} 
mengurus ikan-ikan, burung-burung, dan semua binatang lain yang liar."

Dalam Alkitab bahasa Indonesia mengatakan "menurut gambar dan rupa Kita." Sementara King James menterjemahkan "di dalam gambaran Kita, menjadi persamaan Kita. Sepertinya terjemahan bahasa Indonesia kata "menurut gambar" memberikan gambaran seperti sesuatu yang diletakan untuk dilihat lalu dikerjakan sesuai dengan apa yang dilihat. Sehingga hasilnya seperti sama dengan aslinya.

\section{Analisa Teks Kunci Peijanjian Lama}

Dalam rancangan Allah, sebenarnya Ia telah mengatur agar manusia berpasangan yang hidup untuk beranak cucu dan menguasai bumi, seperti yang dikatakan Alkitab, dalam Kejadian 1:26-27, dikatakan bahwa manusia itu, baik laki- laki dan perempuan diciptakan-Nya dan diberi perintah untuk menguasai segala ciptaanNya. Dengan kehendak Allah, manusia itu disertakan oleh-Nya hak dan kuasa untuk memberikan nama atas segala sesuatu yang diciptakanNya (Kej. 2:19). Namun Alkitab berkata, setiap ciptaan yang dibawa oleh Allah kepada manusia itu tidak ada yang sepadan dengannya. Dengan kata lain manusia itu melihat bahwa di antara semua ciptaan yang dibawa Allah kepadanya tidak ada yang setara dengannya.

Setelah proses pendataan nama, yaitu semua makhluk hidup baik tumbuh-tumbuhan maupun hewan, baik yang ada di darat, laut dan udara telah selesai mendapat nama dari Adam, dan ketika itu juga Adam merasa tidak mendapatkan yang sepadan dengannya, seperti yang Alkitab mengatakan "Manusia itu memberi nama kepada segala ternak, kepada burung-burung di udara dan kepada segala binatang hutan, tetapi baginya sendiri ia tidak menjumpai penolong yang sepadan dengan dia" (Kej. 2:20).

Namun tetapi kemudian, Kejadian 2:21, berkata "Lalu TUHAN Allah membuat manusia itu tidur nyenyak, ketika ia tidur, TUHAN Allah mengambil salah satu rusuk dari padanya, lalu menutup tempat itu dengan daging " Dalam Ensiklopedi Alkitab, dituliskan: "sesudah Allah mengambil satu rusuknya (tslá), Allah membuat (bana, membangun) rusuk itu menjadi perempuan (le isysya). ${ }^{13}$

${ }^{13}$ T. C. Mitchell, "Hawa," dalam Ensikiopedi Alkitab (Jakarta: Yayasan Komunikasi Bina Kasih, 1993), hlm. 1372. 
Tindakan Allah lebih cepat mengatasi kecemburuan manusia terhadap ciptaan-Nya yang lain. Menurut penulis, Tuhan Allah dengan kemahatahuan-Nya menjaga perasaan dan tindakan manusia yang gampang akan membeda-bedakan manusia perempuan dikemudian hari seperti sekarang sehingga Ia tidak membentuk manusia perempuan dan tanah lagi supaya manusia laki-laki tidak dapat mengatakan engkau adalah manusia ciptaan Allah yang kedua. Sehingga Ia membuat manusia itu tidur lalu mengambil tulang rusuk dan dijadikan-Nya manusia perempuan, lalu dibawa-Nya kepada manusia laki-laki itu (Kej. 2:22).

Menurut Tafsiran Masa Kini, penulis buku tersebut menjelaskan Kejadian 2:18 bahwa: "Tidak baik." Hanya bila manusia terdiri dari laki-laki dan perempuanlah pekerjaan pada hari keenam itu dapat disebut "amat baik" (band. 1:27, 31), sebab baru jika demikianlah program kebudayaan ketetapan ilahi itu tumbuh dalam kesempurnaan keturunan (band. 1:28), "Penolong" Perempuan itu dijadikan untuk laki-laki (band. 1 Kor. 1:19), namun bukan sebagai budaknya, melainkan sebagai permaisurinya "Yang sepadan dengan dia" (Ibrani kenegdo), pertama-tama menunjuk kepada kesesuaian, kesamaan (band. ayat 20,23), sama seperti manusia adalah gambar dan kemuliaan Allah, perempuan adalah kemuliaan laki-laki (1 Kor. 1:17). ${ }^{14}$

Kutipan di atas membawa pandangan setiap orang menghantarkan kepada suatu pemahaman baru bahwa laki-laki harus memandang perempuan sebagai pribadi yang diciptakan baginya, tetapi bukan sebagai budak melainkan yang sesuai dan sama dengan dirinya dan sama-sama mengenali diri sebagai pribadi bergambar Allah.

Sepertinya dalam waktu yang singkat perasaan Adam diarahkan kepada kebenaran ayat 18 ini sehingga ketika Hawa, Si perempuan itu dibawa oleh Allah di hadapannya ia berkata "Inilah dia, tulang dari tulangku dan daging dari dagingku. Ia akan dinamai perempuan, sebab ia diambil dari laki-laki” (Kej. 2:23). Dalam tafsiran Wycliffe, Yates, menafsirkan kalimat "inilah...daging dari dagingku" bahwa:

Perempuan (ishshd) laki-laki (ish). Kedua kata Ibrani ini sangat mirip, bahkan juga bunyinya. Satu-satunya perbedaan ialah akhiran feminin untuk perempuan. Berbagai leksikon mutakhir menyatakan bahwa kedua kata ini secara etimologis tidak ada

${ }^{14}$ Meledith G. Kline. "Penciptaan,” dalam Tafsiran Alkitab Masa Kini, (Jakarta: Yayasan Komunikasi Bina Kaslh, 2008); Kejadian-Ester, hlm. 1:84. 
kaitannya. Sekalipun demikian, tidak ada alasan kuat untuk menolak pandangan sebeluinnya bahwa kata yang dipakai untuk "perempuan" berasal dan kata untuk laki-laki). ${ }^{15}$

Wycliffe, sepertinya menunjuk secara umum hanya mengatakan, kedua kata Ibrani ini mirip bahkan bunyinya. Perbedaan hanya terdapat pada akhiran bagi perempuan dan selanjutnya mengatakan kata yang dipakai untuk perempuan berasal dari kata yang digunakan untuk lakilaki. Sehingga penjelasan itu terlalu panjang dan bertele-tele. Namun kebenaran tafsiran tersebut tidak terlalu berbeda dengan ungkapan Tafsiran Alkitab Masa Kini, sangat singkat dan sederhana mengatakan: 'Kesamaan tekanan suara dan 'is' dan 'issá (laki-laki dan perempuan) memantulkan penafsiran nama asli perempuan sebagai suatu bentuk yang diturunkan dan karenanya "semacam dengan" laki-laki (band. 18,20)." 16 Bentuk yang diturunkan semacam dengan laki-laki sangat menekankan ketidakbedaan antara laki-laki dan perempuan. Yang artinya sama-sama adalah manusia. Jadi dalam bahasa Ibrani kata "perempuan" tidak berbeda dengan kata "laki-laki." Artinya kata perempuan semacam dengan laki-laki tidak ada penjelasan tentang kemuliaan masing-masing dalam Alkitab, tetapi pengakuan Adam kepada perempuan sangat jelas "engkaulah dia," "tulang dari tulangku, daging dan dagingku" menekankan ketidak perbedaan antara laki-laki dan perempuan yang memiliki tubuh, jiwa dan roh, atau kehendak, perasaan serta akal budi yang sama.

\section{Analisa Teks Kunci Perjanjian Baru}

Untuk memahami secara biblikal teks kunci dalam Peijanjian Baru mengenai kesetaraan gender ialah terdapat dalam Galatia 3:28, berikut ini akan dikaji secara biblikal. Galatia 3:28 "Dalam hal ini tidak ada orang Yahudi atau orang Yunani, tidak ada hamba atau orang merdeka, tidak ada laki-laki atau perempuan, karena kamu semua adalah satu di dalam Kristus Yesus."

Terdapat tiga elemen penting yang dinyatakan Paulus dalam ayat ini (Yahudi atau Yunani, hamba atau orang merdeka dan laki-laki atau perempuan). Menurut F. F. Bruce, ketiga elemen di atas mungkin

\footnotetext{
${ }^{15}$ Yates, "Penciptaan," dalam Tafsiran Alkitab WYCLIFFE, hlm. 1:29.

${ }^{16}$ Ibid., hlm. 1:85.
} 
disisipkan untuk menyanggah tiga ucapan berkat atau syukur yang disisipkan dalam awal siklus doa pagi orang Yahudi, seperti yang telah disebutkan bahwa laki-laki Yahudi bersyukur kepada Allah bahwa mereka tidak dilahirkan sebagai orang kafir, budak atau perempuan. ${ }^{17}$ Kendati sesungguhya mereka tidak bermaksud untuk menghina kelompok yang mereka sebutkan, namun faktanya mereka tidak memiliki syarat untuk mendapatkan beberapa hak keistimewaan keagamaan yang terbuka untuk laki-laki Yahudi merdeka.

\section{Konteks}

Tekanan utama surat kiriman kepada jemaat di Galatia, sebagaimana diterima secara luas, adalah dua fakta penting yang dialami orang Kristen di dalam Kristus: (1). pembenaran dalam Yesus Kristus melalui iman terlepas dan perbuatan baik (secara legal), dan (2). kehidupan Kristen yang berkemenangan hanya dimungkinkan oleh Roh Kudus, bukan dengan melakukan hukum Taurat. Pertanyaannya adalah "Apakah konteks Galatia 3:28?" Di sini Paulus menekankan pembenaran oleh iman untuk mengoreksi problem sosial dalam jemaat Galatia yang sedang dipengaruhi oleh pemahaman orang Kristen Yahudi bahwa orang percaya non Yahudi tidak termasuk dalam komunitas orang percaya Yahudi karena mereka tidak melakukan hukum Taurat, yaitu karena tidak disunat. Kemudian Paulus menyimpulkan bahwa pembenaran oleh iman seharusnya berarti, "Orang percaya non Yahudi dimasukkan menjadi umat Allah oleh kasih karunia saja!

Bagaimana caranya orang kafir dimasukkan menjadi umat Allah? Mereka menjadi umat Allah melalui status mereka sebagai anak. Dalam ayat 26, Paulus menulis "Sebab kamu adalah anak-anak Allah melalui iman kepada Kristus Yesus." Pernyataan Paulus di sini merupakan keterangan yang menunjukkan bahwa pernyataan tersebut merupakan kesimpulan untuk argumen sebelumnya yang baru saja dijelaskan dalam ayat 23-25. 3:23 Sebelum iman itu datang kita berada di bawah pengawalan hukum Taurat, dan dikurung sampai iman itu telah dinyatakan.3:24 Jadi hukum Taurat adalah penuntun bagi kita sampai

\footnotetext{
${ }^{17}$ F. F. Bruce, Commentary on Galatians, New International Greek New Testament (Grand Rapids: William B. Eerdmans Publishing Company, 1982), hlm. 187.
} 
Kristus datang, supaya kita dibenarkan karena iman. 3:25 Sekarang iman itu telah datang, karena itu kita tidak berada lagi di bawah pengawasan penuntun.

Ini meneguhkan status baru sebagai anak-anak Allah melalui iman kepada Yesus Kristus Perubahan dari orang pertama jamak dan subyek "kita" dalam ayat 23- 25 menjadi orang kedua jamak dan subyek "kamu" dalam ayat 26-29 menunjukkan perubahan fokus yang dramatis, yang menyiratkan bukan hanya orang-orang Yahudi, melainkan juga orang-orang non Yahudi sebagai anak.

James D. G. Dunn menyiratkan bahwa Paulus menggunakan antithesis "kita, kamu" di sini untuk dengan tepat menegaskan pertentangan itu sudah tidak relevan lagi. Tidak ada lagi orang Yahudi atau orang Yunani (3 28), sebab orang percaya Yunani ada di dalam Kristus, dan dengan demikian menjadi keturunan Abraham dan menjadi ahli waris yang diberikan kepada Abraham (3:28-29). ${ }^{18}$

Salah satu isu yang dikemukakan dalam pernyataan Paulus dalam Galatia 3:28 dan juga yang merupakan pembahasan utama penulisan ini ialah berkenaan, kesetaraan antara pria dan wanita. Apakah pria dan wanita juga tidak berbeda? Kata kunci untuk pembahasan ini ialah "tidak ada lagi laki-laki atau perempuan."

Secara umum referensi laki-laki (arsen) dalam Septuaginta mengacu kepada laki-laki seperti dipertentangkan pada perempuan (Mis. Kej. 1:17; 5:2; 17:14, 23; 34:24; Kel. 1:16-18, 22; 12:5; Im. 12:7; 15:33; 27:3,5,6,7; Bil. 5:3). Masalahnya dalam Perjanjian Baru, kata arsen digunakan untuk menunjuk laki-laki dan untuk perempuan sebagai jenis kelamin (gender) laki-laki dan perempuan (Mat. 19:14; Mrk. 10:6; Luk. 2:23; Why. 12:5; Rm. 1:26, 27). Sebab itu, arsen dan thelu tidak dimaksudkan untuk menunjukkan laki-laki dan perempuan dalam pernikahan sebagai suami isteri, melainkan untuk mengacu pada perbedaan kelamin sebagai laki-laki dan perempuan.

Selain itu ada peranan tertentu yang hanya bisa dipenuhi oleh lakilaki, Harun dan anaknya laki-laki sebagai imam (Kel. 31:10; 35:19). Imamat hanya dikhususkan kepada laki-laki. Beberapa ahli menunjukkan bahwa inferioritas perempuan ditunjukkan dalam banyak cara seperti mereka tidak akan diajar hukuin Taurat; mereka diharuskan merawat anak-anak; mereka tidak dipandang sebagai saksi yang bisa

${ }^{18}$ James D. G. Dunn, The Epistles to the Gatians (London: Hendrickson Publishers, 1993), hlm. 202. 
diandalkan dalam pengadilan; mereka bahkan duduk di kursi yang terpisah dar laki-laki di Sinagoga. ${ }^{19}$

Dengan konteks semacam itu, Paulus menuliskan pernyataan ini untuk menekankan perubahan penting yang telah dihasilkan dengan penggantian Pejanjian Lama dengan Peijanjian Baru. Dengan kata lain, Paulus mengatakan bahwa sesuatu telah berubah dengan datangnya Peijanjian Baru. Perubahan itu dinyatakan bahwa perubahan dalam hak-hak istimewa keagamaan sudah tidak relevan lagi dalam konteks Peijanjian Baru. Karena, di dalam Kristus, semua orang merupakan anggota yang setara sebagai "anak-anak Allah" dan partisipan penuh hak-hak istimewa keagamaan di mana perempuan, budak, dan orangorang non Yahudi dikecualikan dalam Perjanjian Lama.

G. Walter Hansen menyatakan bahwa hubungan vertikal yang baru dengan Allah menghasilkan hubungan horizontal yang baru dengan sesama. ${ }^{20} \mathrm{Hal}$ ini berarti bahwa semua penghalang sosial budaya, sosial ekonomi, seksual/ gender tidak berlaku lagi dalam Kristus. Jadi, perhatian utama Paulus di sini ialah untuk mendorong pelaksanaan kesetaraan dan kesatuan semua orang di dalam Kristus dalam kehidupan orang percaya. Dengan kata lain, ungkapan Superioritas rasional (Yahudi atas non Yahudi); superioritas kelas sosial (orang merdeka atau budak); atau superioritas gender (laki-laki atau perempuan) melanggar esensi Injil.

Tentu saja kesetaraan ini tidak menghilangkan perbedaan kebangsaan, status ekonomi dan perbedaan seks seorang Yahudi ketika ia menjadi Kristen, tetap akan menjadi orang Yahudi, demikian juga orang-orang non Yahudi, dan juga budak-budak Kristen tidak akan segera berhenti menjadi budak ketika mereka menjadi Kristen. Jadi, pada intinya, rasul Paulus mengatakan bahwa setelah menjadi satu dengan Allah sebagai anak-anak-Nya. Orang-orang Kristen sekarang menjadi bagian dan orang-orang percaya yang lain sedemikian rupa sehingga perbedaan yang sebelumnya memisahkan mereka, sekarang kehilangan maknanya. Status rohani orang percaya yang baru diterima di hadapan Allah diterima berdasarkan iman yang sama, tanpa memperhatikan latar belakang sosial, sosial dan seksual. Maka jelaslah,

\footnotetext{
${ }^{19}$ M. Knight, Gataians, The VIP Application Commentary (Grand Rapids: Zondervan Publishing House, 1995), hlm. 202.

${ }^{20} \mathrm{G}$. Walter Hansen, Gatian, The IPV New Testament Commentary Series, peny., Grant R. Osborne (Downer Grove, IL: Intervarsity Press, 1994), hlm. 111.
} 
bahwa sesungguhnya kesetaraan pria dan wanita merupakan konsep Alkitabiah yang seharusnya diamalkan oleh setiap orang percaya di segala tempat dan sepanjang waktu.

\section{B. KESIMPULAN}

Untuk menjawab polemik pemikiran pro dan kontra terkait persoalan gender, Kejadan 2:18-25 dari Alkitab Perjanjian Lama dan Galatia 3:25-29 dari Perjanjaian Baru adalah kebenaran yang harus dipercayai sesungguhnya bahwa tidak ada lagi tembok pemisah antara pria dan wanita. Bawha Allah menciptakan manusia laki-laki dan perempuan adalah sama dengan rupa dan gambar-Nya sendiri. Bahwa Kristus datang dan mengubah status orang Yahudi dan bukan Yahudi, laki-laki dan perempuan, Tuan dan hamba menjadi sama melalui karyaNya yang besar, yaitu Kematian-Nya.

Pada penerbitan Jurnal berikut nanti, penulis akan memberikan fakta-fakta Alkitab untuk menguatkan bagian ini bahwa Allah pernah memberdayakan para wanita yang dianggap kaum yang lemah dan nomor dua ini dalam berbagai peristiwa dan momen dalam sejarah Alkitab. Supaya baik pribadi maupun kelompok mengetahui bahwa Allah tidak pernah membedakan manusia laki-laki dan perempuan secara kewibawaan kemuliaannya.

\section{DAFTAR PUSTAKA}

Alkitab. Jakarta: Lembaga Alkitab Indonesia, 2016.

Bacon, Francis. "Marriage and Single Life" Journal Islamia Republika, (9 April 2009).

Barclay, William. dalam Veritas, Jurnal Teologia dan Pelayanan, 4/2 (Oktober 2003).

Bruce, F. F. Commentary on Galatians, New International Greek New Testament. Grand Rapids: William B. Eerdmans Publishing Company, 1982. 
Djannah, F. Teori dan Kosep Gender. Dialog Interaktif antar Tokoh Agama dan Masyarakat (Sosial-Budaya) Provinsi Sumatera Utara. Medan, 26 Juli 2006.

Dunn, James D. G. The Epistles to the Gatians. London: Hendrickson Publishers, 1993.

Gatian, G. Walter Hansen. The IPV New Testament Commentary Series. Disunting oleh Grant R. Osborne. Downer Grove, IL: Intervarsity Press, 1994.

Gataians, M. Knight. The VIP Application Commentary. Grand Rapids: Zondervan Publishing House, 1995.

Lindsey, L. L. Gender Roles: A Sociological Perspective. New Jersey: Prentice, 1990.

Lips, Hilary M. A New Psychology of Women; Gender, Culture, and Ethnicity (2003).

McKay, a History of Western Society, Journal Islamia Republika (9 April 2009).

Megawangi, Ratna. Membiarkan Berbeda. http://muxiim. comiblogs/ najmasyiralkesetaraan-gender/.

Mitchell. T. C. "Hawa.” Dalam Ensikiopedi Alkitab. Jakarta: Yayasan Komunikasi Bina Kasih, 1993.

Rinukti, Nunuk. "Peranan Perempuan Menurut Perjanjian Baru Bagi Perkembangan Kepemimpinan Perempuan Di Dalam Gereja." Jurnal Teruna Bhakti 1, no. 1 (2018): 33-41. http://ejournal.stakterunabhakti.ac.id/index.php/teruna/article/view/9

Sinulingga, R. Perempuan Perlukah Kita Menggugat Kitab Suci? Kurban Yang Berbau Harum. Disunting oleh Darius Duhut, Badan Penelitian dan Pengembangan PGI Jakarta. Jakarta: P01, 1998.

Yates, Kyle M. "Penciptaan." Dalam Tafsiran Alkitab WYCLIFFE. Jilid. 1. Perjanjian Lama: Kejadian - Ester. Disunting oleh Charles F. Pfejffer dan Everett F. Harrison. Malang: Gandum Mas, 2004. 